\title{
The Protection of the Rights to Life and Health in Emergencies: An Examination of the Handling of Covid-19 Pandemic in Nigeria
}

\author{
By BONTUR LUGARD Sunday*
}

\begin{abstract}
The Coronavirus Disease (COVID-19) is inarguably the most disrupting occurrence in human affairs since the World War II. This virus left governments, communities and systems with the legal, social and moral duties to protect from its impacts. However, some of the approaches adopted towards protecting the victims, potential victims, and the entire society, especially in Nigeria, caused more harm than the disease itself. This work reviews the impact of the curtailment measures adopted by governments in Nigeria and their adverse bearing on human rights, especially the right to life as a sacrosanct and universal right. It further examines how law enforcement agencies' operations - within the confines of the institutional and international best practices - their non-adherence to the rules of engagement or principles of ethical operations have resulted in the violation of human rights, rather than protecting them. It also analyses the impact of the virus on the right to health and access to medical facilities in times of emergencies in Nigeria and concludes that both rights were either violated or not realized within the context of the 'war' against the COVID-19 pandemic. This work advocates for the continuous training on human rights responsibilities of law enforcement agents, a more rigorous recruitment process with a minimum qualification from school certificate to ordinary national diploma, the use of video camera in the course of operations, among others that would help safeguard the rights of citizens in times of emergencies like the COVID-19.
\end{abstract}

\section{A. INTRODUCTION}

It has been contended that the severe acute respiratory syndrome coronavirus 2 (SARSCoV-2), the virus that causes COVID-19, is one of the deadliest infectious diseases in recent human history with a yet to be ascertained mechanism for its emergence in humans. ${ }^{1}$ It is so lethal that the United Nations Development Programme statistics indicate that in

* Sunday Bontur Lugard, Department of International Law and Jurisprudence, Faculty of Law, University of Jos, Nigeria, and Partner, Jus Associates (Legal Practitioners - Abuja, Nigeria); lugards@unijos.edu.ng.

1 DM Morens, et al, 'The Origins of COVID-19 and why it Matters' (2020) 103(3) The American Journal of Tropical Medicine and Hygiene $955<\mathrm{https} / / / \mathrm{www} . n \mathrm{cbi} . n \mathrm{~m}$.nih.gov/pmc/articles/P MC7470595/pdf/tpmd200849.pdf $>$ accessed on 18 April 2020; Mohammed A Shereen, et al, 'COVID-19 Infection: Emergence, Transmission, and Characteristics of Human Coronaviruses' 
2020, COVID-19 was the leading cause of death in the world - higher that HIV/AIDS, malaria, road accidents, among others. ${ }^{2}$ A chunk of scientific (virologic, epidemiologic, veterinary, and ecologic) data provides persuasively that this virus emanated whether directly or indirectly from a ' $\beta$-coronavirus in the sarbecovirus (SARS-like virus) group' which normally infects bats and pangolins in Asia.' ${ }^{3}$ The virus causes respiratory difficulties in symptomatic victims, coughing, fever, fatigue, among other symptoms that impair their ability to breathe and sometimes results in death.

Infections from this virus were first recorded in late 20194, in Wuhan (Hubei Province of China), and it spread like wildfire and has become a global pandemic - the fast spread and deadly nature of the virus made the World Health Organization (WHO) to declare it 'COVID-19' on the $11^{\text {th }}$ February, 2020; and by March 11th, 2020 when the number of countries with reported cases of infections had grown to 114, with more than 118,000 cases and over 4000 deaths, WHO declared it a pandemic. ${ }^{5}$ As at today, $21^{\text {st }}$ April 2021, WHO report indicates that there have been 142,238,073 confirmed cases of COVID-19 globally and 3,032,124 deaths resulting from infections by the virus. ${ }^{6}$

In Nigeria, the level of infections, spread and deaths caused by the whirlwind of COVID-19 may be well below global average - this may not be connected with any peculiar preventive or therapeutic measures put in place in the country but an inexplicable intervention of nature. As at today, $21^{\text {st }}$ April, 2021, Nigeria has officially confirmed 164,423 cases of the virus and 2,061 deaths resulting therefrom. ${ }^{7}$ The casualty figure of about 2,000 represents about $0.00103 \%$ of the population of about $200,000,000$ people compared to about $0.17 \%$ (about 31.8 million confirmed cases and 569,185 deaths $^{8}$ ) in a population of about 330,000,000 million people of the United States of America (USA). This intervention of nature is plausible regarding Nigeria, or what the pious Nigerians would refer to as the

(2020) 24 Journal of Advanced Research 91 (abstract) <https://doi.org/10.1016/j.jare.2020.03.005> accessed 21 April 2021.

2 United Nations Development Programme (UNDP), 'COVID-19 and Human Development: Assessing the Crisis, Envisioning the Recovery' (2020 Human Development Perspectives) $4<\mathrm{http} / / \mathrm{hdr}$.un dp.org/sites/default/files/covid-19_and_human_development_0.pdf> accessed 21 April 2021.

3 Morens (note 1).

4 Ibid.

5 Francesco Di Gennaro, 'Coronavirus Diseases (COVID-19) Current Status and Future Perspectives: A Narrative Review' (2020) 17 International Journal of Environmental Research and Public Health 1; World Health Organization Director-General's Opening Remarks at the Media Briefing on COVID-19-11 March $2020<\mathrm{https} / /$ www.who.int/dg/speeches/detail/who-director-general-s-o pening- remarks-at-the-media-briefing-on-covid-19---11-march-2020> accessed on 11 March 2020.

6 World Health Organization (WHO), 'WHO Coronavirus (COVID-19) Dashboard' < https://covid19. who.int/> accessed 21 April 2021.

7 Nigeria Centre for Disease Control (NCDC), 'COVID-19: Nigeria' < https://covid19.ncdc.gov.ng> accessed 21 April 2021.

8 John Hopkins University and Medicine, 'COVID-19 Data in Motion: Wednesday, April 21, 2021' $<$ https://coronavirus.jhu.edu> accessed 21 April 2021. 
grace of $\operatorname{God}^{9}$, considering the poor state of medical facilities and the impediments to access to them compared to the USA. The level of infections in Nigeria is also well below the global average of about $0.039 \%\left(3,050,226\right.$ deaths ${ }^{10}$ out of the global population of about 7.9 billion people ${ }^{11}$ ). If Nigeria had suffered the same level of reported cases in USA or what was experienced in most of Europe, the non-availability or decay in the existing medical infrastructure would have worsened its spread and casualty proportion than what was experienced in most of those Western countries.

Asides the negative impact on human health and death of some of the victims of this pandemic, it also impacted on the lives of individuals and the entire spectrum of human activities the world over in several other ways. COVID-19 further pervasively impacted negatively on the global economy, social interaction, human rights, jobs and employment relations, among others. Since Nigeria, as a member of the global community confirmed the first case of the virus on the $27^{\text {th }}$ February, $2020^{12}$ on its shore, it has influenced governments' policies and actions, which until recently, included the suspension of commercial and private flights to and from the country, the restriction of movements of all persons within the shores of the country, the banning of all manner of gatherings of more than fifty people, among other measures.

\section{B. GOVERNMENT CURTAILMENT APPROACHES}

Considering the deadly impact and the infectious nature of this virus, governments at the national, states and local levels took steps that were aimed at minimizing the spread of this virus and safeguard people within the Nigerian geographical space. This included restriction of movements, contact tracing, suspension of most economic activities, among others in order to curb its impacts on human lives. The President through the COVID-19 Regulations, 2020 - made pursuant to the Quarantine Act ${ }^{13}$, effective from $30^{\text {th }}$ March, 2020, made some regulations regarding Lagos and Ogun states, and the Federal Capital Territory (FCT), Abuja, which included the following:

a. Restriction in movements in the two states and the FCT for two weeks with effects from $30^{\text {th }}$ March, 2020;

b. All travel into or out of the affected states and the FCT were prohibited;

c. All businesses in the affected territories were to be closed down;

9 Nigeria is a very religious country, and every occurrence is ascribed a spiritual or beyond-natural cause.

10 John Hopkins, (note 8).

11 Worldometer, 'Current World Population'<https://www.worldometers.info/world-population/> accessed 21 April 2021.

12 Nigeria Centre for Disease Control (NCDC), 'First Case of Corona Virus Disease Confirmed in Nigeria' $<$ https://ncdc.gov.ng/news/227/first-case-of-corona-virus-disease-confirmed-in-nigeria $>$ accessed 23 April 2020.

13 Cap Q2, Laws of the Federation of Nigeria, 2004. 
d. Commercial and private aircraft operations were banned; and

e. The closure of schools.

However, some exceptions were granted to the following activities: hospitals and medical manufacturing and supply chain; food supply chain; petroleum products distribution and retails entities activities; power generation, transmission and distribution companies' operations; private securities functions; essential telecoms staff whose services could not be undertaken from home; and seaports operations were allowed to function.

At the states level throughout the country, some measures were also taken by the Governors to minimize the spread of the disease, enable contract tracing of persons who have had close contacts with victims, and the isolation of victims for treatment. Some of these countermeasures resulted in the killing of persons, alleged to have violated the stay-at-home order, hence violating their most important and sacrosanct right to life. ${ }^{14}$ Furthermore, some of the victims of the disease were unable to access medical care due to non-availability of spaces in isolation centres/designated treatment hospital - especially in Lagos, Kano and Zamfara States, leading to the violation of both their rights to health and life. ${ }^{15}$

\section{CURTAILMENT MEASURES AND HUMAN RIGHTS}

\section{i. Curtailment Measures}

There is no doubting the fact that these measures aimed at controlling or curtailing the spread of the virus negatively impacted on or impeded the realization of some fundamental rights: the civic and political rights and socio-economic rights, as well, in Nigeria. The main political and civic rights affected by the virus or the response of government to the curtailment of same are the right to life, human dignity, the right to personal liberty, the right to peaceful assembly and association, and the freedom of movement, all of which are guaranteed by sections $33,34,35,40$, and 41 respectively of the Constitution of the Federal Republic of Nigeria, 1999 (as Amended) ${ }^{16}$.

14 These orders were either made by the President or Governors of the various states in relation to their respective entities.

15 See Godsgift Onyedinefu, 'Many COVID-19 Patients not in Isolation Centres due to Shortage of Bed Space - NCDC' (Businessday, Lagos, 8 May 2020) <https://businessday.ng/coronavirus/ article/many-covid-19-patients-not-in-isolation-centres-due-to-shortage-of-bed-space-ncdc/> accessed 30 April 2021. See also Adaobi Tricia Nwaubani, 'Coronavirus: Why Some Nigerians are Gloating about Covid-19' (BBC News, 23 April 2020) <https://www.bbc.com/news/world-afri ca-52372737> accessed 30 April 2021.

16 Cap C 24, Laws of the Federation of Nigeria, 2004 (subsequently referred to as the 1999 Constitution (as Amended)). 


\section{ii. Human Rights Violations}

The socio-economic rights directly impacted by the virus and the approach adopted by the governments in curbing its spread include: the right to health, shelter, education, food, among others. In this piece however, two key rights: the right to life (under the civic and political taxonomy), and the right to health (under the socio-economic rights taxonomy) would be analyzed.

\section{The Right to life}

In the course of enforcing the presidential order for lockdown, security forces in the country between $30^{\text {th }}$ March, 2020 and $16^{\text {th }}$ April of the same month were reported to be responsible for killing of 18 persons, more than those killed by the virus itself - which at the time had killed 12 persons based on official report. ${ }^{17}$ The security forces might have killed several other people unjustly than those reported in the course of enforcing the stay-at-home order made in waging the 'war' against the virus. Considering the top-notch value escribed to human life and the non-derogable nature of the right, except in execution of a court order, extreme cases of self-defence, among others, it is pertinent to undertake an in-depth examination of the impact of the violations of the right in the context in issue.

As the Human Rights Committee wrote in its first General Comment on the right to life under the International Covenant on Civil and Political Rights: 'The deprivation of life by the authorities of the State is a matter of the utmost gravity. Therefore, the law must strictly control and limit the circumstances in which a person may be deprived of his life by such authorities.' 18

It is in recognition of the value of life that all known international human rights instruments recognize it as the most cardinal of all rights. ${ }^{19}$ It is also in this light the above that the Constitution of the Federal Republic of Nigeria 1999 (as Amended) provides that:

17 British Broadcasting Corporation (BBC) 'Coronavirus: Security Forces Kill More Nigerians than Covid-19' (16 April 2020) <https://www.bbc.com/news/world-africa-52317196> accessed 24 April 2021. See also Al Jazeera News Agency, 'Nigerian Security Forces Kill 18 during Curfew Enforcement' (16 April 2020) <https://www.aljazeera.com/news/2020/4/16/nigerian-security-force s-kill-18-during-curfew-enforcement> accessed 24 April 2021.

18 Geneva Academy of International Humanitarian Law and Human Rights, 'The Use of Force in Law Enforcement and the Right to Life: The Role of the Human Rights Council' (Academy In-Brief No. 6, 2016) <https://www.geneva-academy.ch/joomlatools-files/docman-files/in-brief6_ WEB.pdf $>$ accessed 30 April 2021.

19 These include: African Charter on Human and Peoples' Rights (art. 4); American Convention on Human Rights (art. 4); American Declaration of the Rights and Duties of Man (art. 1); Arab Charter on Human Rights (arts. 5-8); Convention on the Protection of the Rights of Migrant Workers and Members of their Families (art. 9); Convention on the Rights of the Child (art. 6); European Convention for the Protection of Human Rights and Fundamental Freedoms (art. 2); Inter-American Convention on the Forced Disappearance of Persons; International Covenant on Civil and Political Rights (art. 6); Protocol No. 13 to the European Convention for the Protection 
Every person has a right to life, and no one shall be deprived intentionally of his life, save in execution of the sentence of a court in respect of a criminal offence of which he has been found guilty in Nigeria.

The wordings of these two legal instruments identify the state as the duty-bearer. Whether the state or its agents are responsible, or any other person within its territory, it owes the responsibility to protect or respect the right as it relates to such person. Asides the execution of court order, other exceptions provided in the 1999 Constitution (as Amended) pertain to a situation where the deceased person 'dies as a result of the use, to such extent and in such circumstances as are permitted by law, of such force as is reasonably necessary. ${ }^{20}$ In addition, permissive instances relate to self-defence, to execute a lawful arrest or to prevent escape from lawful detention, and to suppress a riot, insurrection or mutiny. ${ }^{21}$ Another exception to the responsibility to protect human rights is when national security is threatened - in such instance, human rights of individuals can be suspended in the interest of national security. On this the Nigerian Supreme Court has held in Dokubo-Asari v. Federal Republic of Nigeria ${ }^{22}$ that:

where National Security is threatened or there is the real likelihood of it being threatened human rights or the individual right of those responsible take second place. Human rights or individual rights must be suspended until the National Security can be protected or well taken care of. This is not anything new. The corporate existence of Nigeria as a united, harmonious, indivisible and indissoluble sovereign nation, is certainly greater than any citizen's liberty or right.

The Nigerian Human Rights Commission documented the killing of the 18 persons in various states of the country in enforcement of the presidential stay-at-home order made as 'extra-judicial', since the killings fell short of the constitutional requirements shown above. And this was so tagged because it was not undertaken in execution of any court order nor could it be justified under any of the permissible circumstances provided by the 1999 Constitution (as Amended). Furthermore, as Jared Diamond once observed, '[s]omewhere along the scale from bacteria to humans, we have to decide where killing becomes murder. ${ }^{23}$ These killings, having no constitutional backing cannot but be considered as incidents of

of Human Rights and Fundamental Freedoms concerning the abolition of the death penalty in all circumstances; Protocol to the American Convention on Human Rights to Abolish the Death Penalty; Second Optional Protocol to the ICCPR aiming at the abolition of the death penalty; Universal Declaration on Human Rights (art. 3).

20 Section 33(2).

21 Section 33(2)(a)-(c).

22 (2007) 12 NWLR (Pt. 1048) 320 at 358.

23 Jared Diamond, The Third Chimpanzee: The Evolution and Future of the Human Animal (New York, HarperCollins, 1992) 30, quoted in Elizabeth Wicks, The Right to Life and Conflicting Interests (New York, Oxford University Press, 2010) 2-3. 
murder. For instance, the National Human Rights Commission specifically states, while condemning the wrongful killings thus:

...law enforcement agents have extrajudicially executed 18 persons to enforce the regulations. This speaks volumes of the protocols and rules of engagement for our law enforcement as well the efficiency level and capacity of law enforcement agents to deal with civil population. It's a sheer display of impunity and reckless disregard for human life in law enforcement by security personnel. ${ }^{24}$

The above report negatives any claim or justification from the security agencies. The various security agencies were reported to be responsible for the 'extra-judicial' killing of the 18 persons in this order: the Nigeria correctional Services (responsible for 8 deaths), the Nigeria Police (responsible for 7 deaths), the Nigerian Army (responsible for 2 deaths), and Ebonyi State Task Force on Covid-19, Afikpo South LGA (was responsible for 1 death). ${ }^{25}$ The issue for scrutiny is, was the use of force that resulted in the deaths reported above 'reasonably necessary' in the circumstances? This question begs for answer from the culprits of these acts.

Furthermore, there has been no report of the prosecution of the security agents behind this violation of the right to life of the 18 persons and other persons who were similarly killed afterwards, hence presenting the assailants as operating with utmost disregard for the rule of law.

This state of development is the more so worrisome considering the fact that such deprivation of the right to life cannot be adequately compensated, compared to the violation of other rights. For instance, if a person is deprived of the constitutionally guaranteed right to own property anywhere is Nigeria, a court of law can award him the monetary value of the property and put him in the same position as he would have been if such right had not been violated. But dead men cannot be resurrected by the court as an adequate compensation for the violation of their rights, hence the irreparable nature of issues bordering on the right to life must be accorded topmost priority.

In addition, it is in recognition of the place of the right to life as the number one right that Christian Tomuschat posited that:

Life is tantamount to human existence... Life is the foundation of man as an individual and as a member of society. Accordingly, the right to life is not just any one of the fundamental rights in the lists established by the well-known instruments of human rights protection. A person may exist for quite a long time while being deprived of

24 Except of a Press Release by Tony Ojukwu, the Executive Secretary, Nigerian Human Rights Commission, 'National Human Rights Commission Press Release On Covid-19 Enforcement So Far Report On Incidents Of Violation Of Human Rights' on $15^{\text {th }}$ April, $2020<\mathrm{https}$ ://www.nigeri arights.gov.ng/nhrc-media/press-release/100-national-human-rights-commission-press-release-on -covid-19-enforcement-so-far-report-on-incidents-of-violation-of-human-rights.html $>$ accessed 24 April 2020.

25 Ibid. 
the right to freedom of expression, e.g. but deprivation of life puts a definitive end to all the aspirations and needs of a human being to enjoy an existence in unharmed dignity... Denying someone the right to life is to exclude him/her from human society. On the other hand, no society can flourish where the right to existence of its members is not reliably ensured. If everyone's life is structurally threatened at any time, without any respite, mutual trust among human beings cannot build up. Anarchy and decline will be the unavoidable consequences. ${ }^{26}$

Flowing from the above, it is axiomatic that 'the right to life deserves a special position in the hierarchy of values' ${ }^{27}$ and any case of violation of such right should be subject to legal scrutiny and accountability by the culprit so as to assuage the interest of justice, the family of the deceased and deter the arbitral taking of human lives by others.

The endemic nature of the violation of the right to life of all persons in Nigeria calls for serious concern. ${ }^{28}$ This is not peculiar to the period of the coronavirus but is becoming a reputational baggage associated with the security agencies in Nigeria, particularly the police, that cannot be supported in any civil society. The disregard for ethical operations by the police and extrajudicial killings of suspects, among other reasons, formed the basis for the \#EndSARS protests that rocked the country in $2020 .^{29}$

This calls for major scrutiny of the operations of the security agencies' operations, with special reference to the police. This sort of lack of human rights accountability has led to the practice in certain jurisdictions ${ }^{30}$ that mandates police to use body cameras in the course of operations so as to enhance easy access to evidence of the motif behind their actions

26 Christian Tomuschat, 'The Right to Life - Legal and Political Foundations' in Christian Tomuschat, Evelyne Lagrange, and Stefan Oeter (eds.), The Right to Life (Leiden, Brill/Nijhoff/, 2010) 3 .

27 See Yoram Dinstein, 'The Right to Life, Physical Integrity, and Liberty' in Louis Henkin (ed.), The International Bill of Rights, The Covenant on Civil and Political Rights (New York, Columbia University Press, 1981)114, quoted in Christian Tomuschat, 'The Right to Life - Legal and Political Foundations' in Christian Tomuschat, Evelyne Lagrange, and Stefan Oeter (eds.), The Right to Life (Leiden, Brill/Nijhoff/, 2010) 3.

28 Okechukwu Eme, Chukwuma Okoh and Martin Okeke, 'The Police and Criminal Justice System in Africa: Agenda for Reform' (2009) 4(1) International Journal of Development and Management Review $166<$ https://www.ajol.info/index.php/ijdmr/article/download/51028/39713> accessed on 11 May 2021; Esa Onoja, 'The Relationship between the Constitutional Right to Silence and Confessions in Nigeria' (2013) 6 African Journal of Legal Studies 189-211; Richard Aborishade, 'Accounts of Unlawful Use of Force and Misconduct of the Nigerian Police in the Enforcement of COVID-19 Measures' (2021) Journal of Police and Criminal Psychology <https:// link.springer.com/content/pdf/10.1007/s11896-021-09431-4.pdf> accessed on 11 May 2021.

29 Sada Malumfashi, 'Nigeria's SARS: A brief history of the Special Anti-Robbery Squad' (Aljezeera, 22 October 2020) <https://www.aljazeera.com/features/2020/10/22/sars-a-brief-history-of -a-rogue-unit> accessed 11 May 2021.

30 Kate Mather, Divided Police Commission Approves Rules for LAPD Body Cameras, L.A. TIMES (Apr. 28, 2015), quoted in Ethan Thomas, 'The Privacy Case for Body Cameras: The Need for a Privacy- Centric Approach to Body Camera Policymaking' (2017) Columbia Journal of Law and 
in relation to crime prevention and arrests. The case of Derek Chauvin is quite instructive as the evidence from the body camera he used was relied on in establishing his criminal liability and subsequent conviction in his recently publicized trial for killing George Floyd last year in the United State of America. ${ }^{31}$ This approach is necessary in Nigeria. It is plausible that Lagos State government is already adopting this approach ${ }^{32}$ in checkmating police and other law enforcement personnel's brutality and unethical behaviour in relation to observing their human rights responsibilities in law enforcement undertakings.

Other remedies to reckless disregard for human rights protection, especially the right to life in the course of security agents' operations is the need to review the minimum entry requirement into the security services, especially the Nigeria Police, to diploma level. It is easier to train personnel with post-secondary education qualification on issues of human rights and accountability that those with SSCE, especially considering the value of human life and the skill required for civil policing. In addition, relevant, constant training of the personnel is another requirement for improved performance and accountability for human rights protection. Asides the security agents' performance in emergencies, the executive policy direction and regulatory approach to tackling the emergency requires scrutiny.

\section{The Right to Health}

No meaningful discussion about the right to life can be discussed without reference to the right to health which is by nature categorized under the socio-economic rights taxonomy. Though this is not a fundamental right in Nigeria, but as a 'policy-driven' right, it is non-derogable just like the right to life, because of its undeniable importance as a precursor to the realization of the right to life.

\section{LEGAL AND POLICY FRAMEWORK FOR HEALTHCARE RIGHTS IN NIGERIA}

As has been earlier pointed out in this work, the non-availability of medical facilities impeded some victims of the virus' access to treatment. The Nigerian healthcare system has no provision for the sort of pandemic-driven emergencies experienced during the peak of COVID-19 challenge in 2020 and early 2021. For instance, Lagos, Kano and Zamfara States were unable to provide attention to victims of the virus in their states for the purpose

Social Problems 193-4 <http://jlsp.law.columbia.edu/wp-content/uploads/sites/8/2017/03/50-Tho mas.pdf $>$ accessed 11 May 2021.

31 Eric Levenson and Aaron Cooper, 'Derek Chauvin's body camera video shows his reaction just after George Floyd left in an ambulance' (CNN Edition, 1 April 2021) $<$ https://edition.cnn.com/20 21/03/31/us/derek-chauvin-trial-george-floyd-day-3/index.html> accessed 11 May 2021.

32 Gbenga Salau and Jesutomi Akomolafe, 'Lagos kits LASTMA, VIO, others with body cameras to check abuse, crime' (Guardian, 1 April 2021) <https://guardian.ng/news/nigeria/lagos-kits-lastma -vio-others-with-body-cameras-to-check-abuse-crime/> accessed on 11 May 2021. 
of treatment ${ }^{33}$ because the existing infrastructure was saturated and medical personnel overwhelmed by the number of patients. The federal government and Lagos State had to construct urgent health centres and other health facilities or convert some structures for use as medical centres in order to carter for victims of the virus; the president had to even make urgent approval of about 17 million dollars for the construction or repairs of oxygen plants due to shortage of oxygen. ${ }^{34}$ At some point, some victims lost their lives as a result of nonavailability of oxygen in some Nigerian hospitals or the lack of ventilators to carter for those critically sick due to infection from the virus. ${ }^{35}$

Several legal and policy frameworks are recognized in Nigeria for the protection of the right to health. These range from international legal instruments that the country has ratified, or domestic legal instruments made as frame or premise for the actualization of the right.

\section{i. International Instruments}

The preamble to the Constitution of the World Health Organisation contextualizes its concept of health to entail:

... a state of complete physical, mental and social well-being, not merely the absence of disease or infirmity. The enjoyment of the highest attainable standard of health is one of the fundamental rights of all human beings without distinction as to race, colour, and religion. ${ }^{36}$

Historically, the right to health was conceived in the $20^{\text {th }}$ century with its earliest mention in the World Health Constitution of $1946^{37}$, shortly before its passive recognition in article 25(1) of the Universal Declaration on Human Rights ${ }^{38}$ which provides that:

(1) Everyone has the right to a standard of living adequate for the health and wellbeing of himself and of his family, including food, clothing, housing and medical care

33 Onyedinefu (note 15) above.

34 Africa News, 'Nigeria's Lagos Struggles to Care for COVID-19 Patients' (Africa News, 23 January 2021) <https://www.africanews.com/2021/01/23/nigeria-s-lagos-struggles-to-care-for-covi d-19-patients//> accessed 30 April 2021.

35 Sylvester Ikhisemojie, 'Patients Dying from Lack of Oxygen in Nigerian Hospitals' (Punch, 14 January 2021) <https://punchng.com/patients-dying-from-lack-of-oxygen-in-nigerian-hospitals/> accessed 30 April 2021.

36 The Constitution of the WHO was adopted by the International Health Conference, New York, 19-22 June 1945; opened for signature on 22 July 1946 by the representatives of 61 states; 14 UNTS $185<$ https://www.who.int/about/who-we-are/constitution>.

37 AM Gross, "The Right to Health in an Era of Privatisation and Globalisation, National and International Perspectives" 293.

38 United Nations, 'Universal Declaration of Human Rights' < https://www.un.org/en/udhrbook/pdf/u dhr_booklet_en_web.pdf $>$ accessed 13 November 2020. 
and necessary social services, and the right to security in the event of unemployment, sickness, disability, widowhood, old age or other lack of livelihood in circumstances beyond his control.

This was fortified by the specific provision in the 1966 International Covenant on Economic, Social and Cultural Rights. ${ }^{39}$ Article 12 of the Covenant proclaims:

1. The States Parties to the present Covenant recognize the right of everyone to the enjoyment of the highest attainable standard of physical and mental health.

2. The steps to be taken by the States Parties to the present Covenant to achieve the full realization of this right shall include those necessary for:

(a) The provision for the reduction of the stillbirth-rate and of infant mortality and for the healthy development of the child;

(b) The improvement of all aspects of environmental and industrial hygiene;

(c) The prevention, treatment and control of epidemic, endemic, occupational and other diseases;

(d) The creation of conditions which would assure to all medical service and medical attention in the event of sickness.

The provisions of this instrument appear to be the most comprehensive as it sets the details of the spectrum of State parties' responsibilities towards their people. This ranges from preventive approach through action on hygiene, regards for the most vulnerable group children, and access to "medical service... in the event of sickness." 40 The approach adopted in this instrument is commendable as it covers several elements of the right that every legal or policy framework on the right to health should cover - access.

Another international instrument that Nigeria has ratified and even domesticated is the African Charter on Human and Peoples' Rights ${ }^{41}$ (African Charter) which was developed as a regional response to egregious human rights abuses perpetrated by some post-independence African political leaders. ${ }^{42}$ Article 16 of the African Charter provides that,

1. Every individual shall have the right to enjoy the best attainable state of physical and mental health.

2. State Parties to the present Charter shall take the necessary measures to protect the health of their people and to ensure that they receive medical attention when they are sick.

39 International Covenant on Economic, Social and Cultural Rights 1966.

40 Ibid.

41 Adopted 27 June 1981, OAU Doc. CAB/LEG/67/3 rev. 5, 21 I.L.M. 58 (1982), entered into force 21 October 1986).

42 Oji U. Umozurike, The African Charter on Human and Peoples' Rights (1997) [hereinafter Umozurike, The African], cited in RN Nwabueze, "The Legal Protection and Enforcement of Health Rights in Nigeria" (2014) in C. Flood and A Gross (Eds.), The Right to Health at the Public/Private Divide: A Global Comparative Study (Cambridge University Press, 2014) 371-393. 
It has been contended that the immediate enjoyment and claim of this right was doubted by eminent scholars and considered to be on the same level as mere fundamental objectives and directive principles of state policy under chapter II of the 1999 Constitution (as Amended), which by its nature is not justiciable. But the sting of this argument has been watered down by the position of the African Commission on Human and Peoples' Rights in the famous case of Social and Economic Rights Action Centre (SERAC) v. Nigeria ${ }^{43}$, in which case the African Commission welcomed the "opportunity to make clear that there is no right in the African Charter that cannot be made effective."

In addition, the African Charter having been domesticated in Nigeria ${ }^{44}$ has the force of law and is on the same pedestal with any enactment of the Nigerian National Assembly. To deepen the discussion on the right to health, it has been argued that the right to life guaranteed by the 1999 Constitution (as Amended) would make no meaning if the adequate healthcare is not provided and access to same is not guaranteed. Nigeria being a signatory to the above instruments is under obligation to promulgate local legislation that recognize such right and set up a system that facilitates its realization, especially in times of emergencies or a pandemic like COVID-19.

\section{ii. Domestic Legal Framework}

Considering the unsavoury state of human health and the numerous impediments to accessing good healthcare services in the country, the government has made attempts through legal framework to address this challenge.

\section{a. The Constitution of the Federal Republic of Nigeria 1999 (as Amended)}

This though falls under the unenforceable chapter II of the Constitution of the Federal Republic of Nigeria, 1999 (as Amended) ${ }^{45}$, it is required of governments at all levels to prioritize the provision of healthcare facilities for the protection of the citizens' wellbeing. Section 17(3) provides that

"The State shall direct its policy towards ensuring that-... (c) the health, safety and welfare of all persons in employment are safeguarded and not endangered or abused; (d) there are adequate medical and health facilities for all persons.... "46

43 Case No. Achpr/Comm/ A044/1. African Commission on Human and Peoples' Rights, May 27, 2002.

44 As African Charter on Human and Peoples' Rights (Ratification and Enforcement) Act, Cap A9, Laws of the Federation of Nigeria, 2004.

45 Cap. C 24, Laws of the Federation of Nigeria 2004 (subsequently referred to as the 1999 Constitution (as Amended)).

46 Section 17(3), Constitution of the Federal Republic of Nigeria 1999 (as Amended). 
The executable potency inherent in rights claims was sapped away from the above provision by section 6(6)(c) of the same Constitution which makes matters taxonomized under chapter II (to which the right to health belongs) non-justiciable. The purport of this is that the right to health can only guide policy making towards the issue of healthcare and related matters, but the government cannot be compelled to recognize or take action regarding the realization of the right as relating to an individual or a group of them in the country. This defect can only be cured by positive legislation by the National Assembly recognizing such a right. In this context, it would appear the National Health Act is an attempt to provide the operative legislation for the recognition of the right to health in Nigeria beyond its being considered a mere policy issue. In the case of Attorney General of Ondo State v. Attorney General of the Federation \& Ors. ${ }^{47}$ where the apex court in support of the approach being advocated by this research held that,

Since the subject of promoting and enforcing the observance comes under the exclusive legislative list it seems to me that the provisions of item 68 of the exclusive legislative list come into play. Therefore, it is incidental or supplementary for the $\mathrm{Na}$ tional Assembly to enact the law that will enable the ICPC to enforce the observance of the fundamental objectives and directive principles of state policy.

This judicial pronouncement gives vigour to the enforceability of "rights" recognized under chapter II of the 1999 Constitution (as Amended).

\section{b. The National Health Act ${ }^{48}$}

This piece of legislation is the most recent in the attempt towards addressing health issues and access to health facilities in the country. The Act sets up the National Health System with the mandate to "provide for persons living in Nigeria the best possible health services within the limits of available resources" 49 and to also "protect, promote and fulfil the rights of the people of Nigeria to have access to health care services." ${ }^{\prime 50}$ This is in sync with the policy of the government as set out in section 17 of the 1999 Constitution.

Furthermore, this Act would appear to be the legal framework necessary to facilitate the realization of the right as already recognized constitutionally, even though as a mere policy that the government should aspire to attain. Achieving good healthcare and to accord citizens access to good and affordable health facilities as a matter of right is seriously an issue of availability of resources. Where the resources are not available, attaining this feat becomes impracticable. The case of Nigeria is the more worrisome that even the available resources are not properly allocated for the benefit of the citizens due to large-scale

47 (2002) 9 NWLR (Pt.772) 222.

48 National Health Act, Act No. 8 of 2014.

49 Section 1(1)(c), ibid.

50 Section 1(1)(e), ibid. 
corruption. It was in recognition of this reality that the African Charter makes reference to "best attainable healthcare" 51 as a limit to the claim of such right as government can only facilitate the realization of such right "within the limits of available resources." 52

Though the boundary set by legislation which recognizes the limit of "availability of resources" was intended to impose a realizable obligation on government, it has turned out to be one of the impediments to the realisation of this right. The implication is that the attainment of this right would always depend on the government's ability to provide the infrastructure and other supporting structure necessary for the realization of the right. However, the fundamental premise that underscored the advocacy and the subsequent legal recognition of socio-economic and cultural rights is that the "attainment of a certain level of social and economic living standard is a necessary condition for the enjoyment of negative rights [civic and political rights]. These rights therefore entail positive obligations on government to provide the living conditions without which the negative rights cannot be enjoyed." ${ }^{53}$ It would amount to an abdication of responsibility for governments to evade the duty of providing all that is necessary for the realization of the right to health. In reality, the right to life and dignity of human person provided for under sections 33 and 34 of the 1999 Constitution (respectively) would make no meaning if the citizens' right to health is not guaranteed. Any conception of human rights intended to protect the things most vital for a person's existence in the world and their ability to live a life of dignity and equality, free of degradation and with the capacity to make the most meaningful choices in life, will accord health a prominent status. In times of calamities and health emergencies like the COVID-19, proper planning, collaboration, with private healthcare services providers are necessary to defeat an infectious disease like COVID-19.

The Act further establishes the National Health System which has a national spread and is meant to provide for health care services and facilities from primary to tertiary level. In addition, the Act empowers the Minister of Health to, in consultation with the National Council on Health prescribe conditions for eligibility to free medical services in public health centres and that "all Nigerians shall be entitled to basic minimum package of health services." ${ }^{54}$ In order to underwrite the cost of medical services for citizens, the Act creates a fund (Basic Health Care Provision Fund) ${ }^{55}$ The sources of contribution to the fund are: a minimum of $1 \%$ of the consolidated revenue fund, grants from international donor parties, among others. Section 11(3) sets up the disbursement structure: $50 \%$ of the fund is for primary and secondary health care facilities through National Health Insurance Scheme, $20 \%$ of the fund is meant for drugs and medical consumables, $15 \%$ for the procurement and

51 Article 16(1). Emphasis mine.

52 See this caveat in section.

53 Osita Nnamani Ogbu, Human Rights Law and Practice in Nigeria, $2^{\text {nd }}$ ed. (Snaap Press Ltd., Enugu, 2013) 26.

54 Section 3, ibid.

55 Section 11, Ibid. 
maintenance of health care facilities, $10 \%$ for human resource development, $5 \%$ for emergency medical treatment. The states and local governments are however required to access funding for project development from the fund subject to contributing at least $25 \%$ of the funds needed for such project. ${ }^{56}$

It is obvious that $95 \%$ of the funds from the above Basic Health Care Provision Fund is meant to be spent on medical facilities and $5 \%$ on medical emergencies. COVID-19 is one of such 'medical emergencies' that the $5 \%$ of the fund was supposed to address. But in the whole discussion about funding the fight against the virus, there was no mere mention of any such fund much less accessing funds from it to provide lacking infrastructure.

There is no provision for underwriting the bills of the indigent who may not be able to afford those services, even if the "facilities" are available. This means even if the lacking medical infrastructure are provided, from the above funds, the realization of the right to health, especially in the poverty-stricken rural areas of the country would still not yet be uhuru. A portion of the fund should legally be provided for the payment of medical bills, including the purchase of drugs, of the vulnerable and indigent citizens in order to widen the space for access to healthcare beyond merely making the facilities available. Of course, of what value would the facilities be, if access is not guaranteed? In addition, in order to avoid the abuse of the privilege of free access to medical facilities by the vulnerable and indigent citizens, government can specifically collaborate with the private sector and other highly-spirited individuals to contribute to the fund with the intent of using the funds specifically for the medical bills of the vulnerable and indigent, since the National Health Act did not make provisions for that. And for this group to access the free medical care, they have to be registered for free under the insurance scheme and their claim of fitting into this group verified at the community level.

The provisions of this Act are laudable on paper but do not have any reflection on ground as far as the state of medical care in the country is concerned. The cost of access to good medical care is still high and beyond the reach of the common Nigerian. In addition, the requirement for out-of-pocket-payment makes access the more difficult as sick person who can afford the medical services may not have access to immediate financial support to enable them pay for their medical bills. This further jeopardizes the survival of such persons. It was in the light of this challenge that limits access to medical care that the idea of an insurance scheme was nurtured and birthed in the country. And at times of medical emergencies like the one posed by COVID-19, it is necessary that its relevant provisions and its enforcement be scrutinized.

\section{c. The National Health Insurance Scheme Act ${ }^{57}$}

The Act was promulgated in 1999 and came into force in 2005.

56 Section 11(5), ibid.

57 Cap N42, Laws of the Federation of Nigeria 2004. 
Section 16 (1) of the $\mathrm{Act}^{58}$ provides that:

An employer who has a minimum of ten employees may, together with every person in his employment, pay contributions under the Scheme, at such rate and in such manner as may be determined, from time to time, by the Council.

(2) An employer under the Scheme shall cause to be deducted from an employee's wages the negotiated amount of any contribution payable by the employee and shall not, by reason of the employer's liability for any contribution (or penalty thereon) made under this Act, reduce, whether directly or indirectly, the remuneration or allowances of the employee in respect of whom the contribution is payable under this Act.

1. The objectives of the Scheme shall be to-

(a) ensure that every Nigerian has access to good health care services;

(b) protect families from the financial hardship of huge medical bills;

(c) limit the rise in the cost of health care services...

(e) maintain high standard of health care delivery services within the Scheme

(f) ensure efficiency in health care services

(g) improve and harness private sector participation in the provision of health care

(h) ensure adequate distribution of health facilities within the Federation;

(i) ensure equitable patronage of all levels of health care;

(j) ensure the availability of funds to the health sector for improved services.

This Act envisages a health care system that will cover all strata of society in all urban and rural communities; however, coverage has so far been limited to public and large private organisations - the 2018 Nigerian Demographic and Health Survey data shows that only $3 \%$ of women and men ages $15-49$ have health insurance in the country. ${ }^{59}$ This low level of coverage is an indication that the goal of the scheme to attain universal coverage and access is still far off the finish mark. In any case, this is not the most vulnerable group in times of medical emergencies like COVID-19 as those who are disposed to dying more from the virus are those from age 60 and above, and those with underlining medical conditions that have impeded their optimal immune system's functionality. ${ }^{60}$

In addition, this Act

58 Ibid.

59 National Population Commission, "Nigeria Demographic and Health Survey: 2018 " $48<$ https://dh sprogram.com/pubs/pdf/FR359/FR359.pdf> accessed 13 November 2020.

60 WHO, 'COVID-19: Vulnerable and High Risk Groups' < https://www.who.int/westernpacific/emer gencies/covid-19/information/high-risk-groups > accessed 30 April 2021. 


\section{E. THE RIGHT TO HEALTH AS A PREMISE FOR ACCESSING MEDICAL CARE IN EMERGENCIES?}

Considering sections 17 (3)(d) and 6 (6)(c) of the 1999 Constitution (As Amended), there is no doubting the fact that the grundnorm merely makes the right to health a policy issue and not a legal right. But in view of the decision in Ondo State v. Attorney General of the Federation \& Ors. ${ }^{61}$ and section 1 (1)(e) of the National Health Act ${ }^{62}$, would it be right to conclude that the legislative backing required for the recognition of the right to health as an enforceable stand-alone right in Nigeria has been supplied? This research answers this poser in the affirmative as the key threshold for the moving of the constitutional provision in section 17 from the policy column to the enforceable legal right column merely requires the promulgation of a legislation to that effect by the national assembly.

Furthermore, there are two other premises for the conclusion that healthcare has been accorded a legal right value in Nigeria: the domestication of the African Charter on Human and People's Rights ${ }^{63}$, especially article 16 thereof which provides that:

(1) Every individual shall have the right to enjoy the best attainable state of physical and mental health.

(2) States parties to the present Charter shall take the necessary measures to protect the health of their people and to ensure that they receive medical attention when they are sick.

To further emphasize its applicability as a legislation that forms part of Nigeria law, the Court of Appeal recently, while relying on the Supreme Court's decision in Abacha v. Fawehinmi ${ }^{64}$ recently held that:

... By the Act, the African Charter constitutes part of the laws of Nigeria which must be upheld by all courts in Nigeria. The African Charter is also given recognition by Chapter IV of the Constitution of the Federal Republic of Nigeria, 1999 as well as the Fundamental Rights (Enforcement Procedure) Rules enacted pursuant to section 46(3) of the Constitution which is one of the ways to enforce the right guaranteed by the African Charter and Chapter IV of the Constitution. ${ }^{65}$

The above decision of the Court makes the provisions of the African Charter clearly enforceable by Nigeria courts. The major challenge or huddle however is the claim of nonavailability of the resources required for the furthering of this ambitious legal provision. Section 1 (1)(c) of the National Health Act subjects the realization of this right to the

61 National Population Commission, (note 73) above.

62 National Health Act, Act No. 8 of 2014.

63 As African Charter on Human and People's Rights (Domestication and Enforcement) Act Cap. A9, Laws of the Federation of Nigeria, 2004.

64 NWLR (Pt. 660) 228.

65 Usman \& Ors v. COP, Plateau State Command \& Anor. (2020) 10 NWLR (Pt. 1732) 262. 
confines of resources - "within the limits of available resources." This gives a readily available defence to the authorities to always raise the lack of resources as the basis for nonprovision of health services and any action required to make medical facilities available and accessible to citizens of the country. This being the case, the right to health is not a sacrosanct claim, if no inexorable legal duty to provide the required environment for the enjoyment of this right is imposed on the duty-bearer - that should engender universal access to good healthcare on a sustainable basis.

The second approach to the claim of existing right to health in Nigeria can be built around the derivative (indirect) interpretation of the right to life guaranteed by section 33 of the 1999 Constitution. ${ }^{66}$ It has been argued that the right to life as guaranteed in the Constitution would make no meaning except the right to good and accessible healthcare is realized. This derivative approach to constitutional interpretation was mainly developed in India and has been deployed in several jurisdictions, including Nigeria.

It is in the light of this development that Gross has contended that key background conditions of right to life include clean drinking water, sanitation, adequate nutritious food, environmental health and occupational health as necessary conditions for the realization of the right to life. ${ }^{67}$

\section{F. PRESIDENTIAL POWERS OVER HUMAN RIGHTS PROTECTION DURING EMERGENCIES}

The 1999 Constitution (as Amended) makes provisions for how an emergency of COVID-19 proportion can be handled by the President. It provides for the powers of the President to restrict certain fundamental rights of all persons in the country during times of emergencies. It specifically provides in section 305(1) thus: 'Subject to the provisions of this Constitution, the President may by instrument published in the Official Gazette of the Government of the Federation issue a Proclamation of a state of emergency in the Federation or any part thereof.' Furthermore, the President is required to present the gazetted proclamation to both Houses of the National Assembly for their approval, or if not satisfied, withhold the approval. ${ }^{68}$ Situations that may warrant the proclamation of state of emergency include: war or danger of imminent war, breakdown of public order or threat of same, disaster or natural calamity. ${ }^{69}$ The President is also empowered to make similar proclamation, in times of public emergencies, regarding any state or part of the country whether on the invitation of the governor or where such governor neglects to do so. ${ }^{70}$

66 Nwabueze, 372.

67 Gross, AM, "The Right to Health in an Era of Privatisation and Globalisation: National and International Perspectives" in Exploring Social Rights: Between Theory and Practice 295 (Daphne Barak-Erez \& Aeyal M. Gross eds., 2007).

68 Section 305(2), Constitution of the Federal Republic of Nigeria 1999 (as Amended).

69 Section 305(3)(a)-(g), ibid.

70 Section 305(4)-(5), ibid. 
Since proclamations are not meant to last forever, the Constitution envisioning this also requires that it ceases to have the effect of law when revoked by the President, the National Assembly (if in session) fails to pass a resolution supported by two-thirds majority of members of both Houses within two days, or where the National Assembly is not in session within ten days of the issuance of the proclamation by the President. ${ }^{71}$ The proclamation also lasts for a maximum period of six months, except a resolution in similar manner is passed extending it for another period of six months. ${ }^{72}$

The president instead of making a proclamation of a state of emergency due to COVID-19 pandemic, he chose in his own wisdom to make regulations pursuant to the Quarantine $\mathrm{Act}^{73}$ which enabled him to take measures that affected the human rights of the citizens without resorting to the national assembly. This decision, though not unlawful in itself, impugned on the possibility of accountability prescribed by the Constitution.

\section{i. Use of Force in Emergencies by Law Enforcement Agents and the Right to Life}

Asides the code of conduct for police offices and rules of engagement for military officers and other law enforcement agents in Nigeria, the operations of law enforcement agents in the country is also guided by international best practice codes. The United Nations Code of Conduct for Law Enforcement Officials ${ }^{74}$ and the Basic Principles on the Use of Force and Firearms by Law Enforcement Officials ${ }^{75}$, considered under international law to form part of customary international law and general principles of law, ${ }^{76}$ make specific provisions on standard of behaviour required by law enforcement officials. These Codes by their very nature are arguably binding on States, as being on the same level as treaties and convention; and even if they were not, they inarguably possess persuasive influence over operational guidelines of member States' law enforcement protocol, including Nigeria. ${ }^{77}$

The United Nations Code of Conduct for Law Enforcement Officials provides that Law enforcement officials in the performance of their duty 'shall respect and protect human

71 Section 305(6), ibid.

72 Ibid.

73 Cap Q2 (note 42) above.

74 Adopted by General Assembly resolution 34/169 of 17 December $1979<$ https://www.ohchr.org/D ocuments/ProfessionalInterest/codeofconduct.pdf $>$ accessed 26 April 2021.

75 Adopted by the Eighth United Nations Congress on the Prevention of Crime and the Treatment of Offenders, in Havana, Cuba, on the 27th August to 7 th September 1990.

76 These are primary sources of international law - see Geneva Academy of International Humanitarian Law and Human Rights (note 18).

77 In Benzer\& Others v. Turkey (Application No. 23502/06); the judgment of the European Court of human Right was given on the $24^{\text {th }}$ March, $2014<$ http://hudoc.echr.coe.int/eng?i=001-128036> accessed 30 April 2021. 
dignity and maintain and uphold the human rights of all persons. ${ }^{78}$ It only permits them to 'use force only when strictly necessary and to the extent required for the performance of their duty. ${ }^{79}$ The commentary to article 3 of the Code further elucidates on the nature of the duty of such official thus:

The use of firearms is considered an extreme measure. Every effort should be made to exclude the use of firearms, especially against children. In general, firearms should not be used except when a suspected offender offers armed resistance or otherwise jeopardizes the lives of others and less extreme measures are not sufficient to restrain or apprehend the suspected offender... ${ }^{80}$

This requires that firearms be used against persons only in extreme circumstances (in self-defence, to protect others in the face of imminent threat to life or serious injury, to prevent the commission of a serious crime, among others) as an matter of last resort. Even where that is the case, the official is further required to do so 'only when less extreme means are insufficient to achieve these objectives. In any event, intentional lethal use of firearms may only be made when strictly unavoidable in order to protect life. ${ }^{91}$ Article 8 of the Basic Principles forbid the reliance on public emergencies as a basis for the use of such weapons on humans. It specifically provides that 'Exceptional circumstances such as internal political instability or any other public emergency may not be invoked to justify any departure from these basic principles.' 82

The international operational codes have been incorporated into the operational manuals of Nigeria Police, the Armed Forces and the Nigeria Correctional Service, among other law enforcement agencies. For instance, Force Order 237 of the Nigeria Police requires that use of firearms would only be permissible where done in self-defence and such attack is of life-threatening proportion or in defence of another confronted with similar life-threatening attack. ${ }^{83}$ It also states that '[i]t would be difficult to justify the use of the firearm if attacked by an unarmed man.' ${ }^{84}$ Where attacked, and the use of firearm is in self-defence, it is further expected that such fire should be directed at the knee of the assailant ${ }^{85}$ and not be shot with intent to kill. This Code may not be a direct adoption of the international Codes, but their provisions are similar. This entails the act of unjustifiable use of firearm

78 Article 2, ibid.

79 Article 3, ibid.

80 See commentary (c) to article 3 , ibid.

81 See article 9 of the Basic Principles on the Use of Force and Firearms by Law Enforcement Officials, adopted by General Assembly resolution 34/169 of 17 December $1979<$ https://www.oh chr.org/Documents/ProfessionalInterest/codeofconduct.pdf> accessed 26 April 2021.

82 Article 8, ibid.

83 Article 3, Force Order 237.

84 Article 4, ibid.

85 Article 6, ibid. 
against unarmed persons who violated the stay-at-home presidential order was criminal and should be subjected to prosecution under Nigerian law as required by Article 7 of the Basic Principles on the Use of Force and Firearms by Law Enforcement Officials ${ }^{86}$ which provides that: 'Governments shall ensure that arbitrary or abusive use of force and firearms by law enforcement officials is punished as a criminal offence under their law.' Doing this would serve two purposes: deterrence and assuaging the family of the deceased that justice has been done.

\section{G. CONCLUSION}

There is no guessing the fact that the rights to life and health are key to establishing the importance of humans as the most civilized specie of beings. While the right to life mainly creates negative obligation on governments to ensure they do not take human lives, without resort to established principles of law, especially by obtaining the order of law courts, it by necessary implication creates positive obligation on government to provide all that is necessary for the realization of this most important right in our statute books. Key among those rights that must co-exist with the right to life to make its realization feasible is the right to health and access to good healthcare facilities, without which the principal right becomes a mirage. The Nigerian security or law enforcement agents need to undergo severe and continuous training on human rights protection, consistent with their rules of engagement and ethics in order for the system to avert the sort of loss of human lives experienced in the course of prosecuting the presidential order made pursuant to the Quarantine Act during the COVID-19 pandemic.

The right to life and its associate, the right to health, must not just be given their priority of place during pandemics but at all times in the course of law enforcement. It is their observing the established procedure in their operations that differentiate between civil law enforcement and the crude ones found in failed states. Where these rights are violated, as in the course of prosecuting COVID-19 regulations, without establishing any legal justification for their violation, it portends danger for human life, and realization of all other rights which make no meaning without the right to life.

86 Adopted by the UNGA, (note 40) above. 